\title{
Adsorption of Pd (II) and Au (III) Ions by Commercial Tris(2- Aminoethyl) Amine Polystyrene Polymer Beads
}

Merve Özçelika, Mustafa Can*b, and Mustafa İmamoğlua

a Department of Chemistry, Sakarya University, Sakarya, Turkey

b Department of Metallurgical and Materials Engineering, Sakarya University of Applied Sciences, Sakarya, Turkey.

\section{* Corresponding Author:}

Mustafa Can, Sakarya University of Applied Sciences, Technology Faculty, Department of Metallurgical and Materials Engineering, Esentepe Campus, 54187, Sakarya, Turkey. mustafacan@subu.edu.tr; Tel.: +90 (264) 6160589 


\section{Abstract:}

Adsorption of gold, rhodium, platinium, and palladium species containing chlorine ions species onto commercial $\mathrm{N}-\{2$-[Bis(2-aminoethyl)amino]ethyl $\}$ aminomethylpolystyrene polymer beads (TRIS) were investigated. The influence of the $\mathrm{pH}$, initial metal ion concentration, and contact time on the adsorption performance was examined in a batch adsorption experiment. Langmuir, Modified Langmuir, Freundlich and Freundlich, Dubinin-Radushkevich isotherm model variables are calculated. The Langmuir monolayer adsorption capacities of the Pd (II), and Au (III) chlorine ions species were found to be 204.5 , and $168.5 \mathrm{mg} / \mathrm{g}$, respectively. The two metal adsorption kinetics fit the pseudo-second order kinetic models. In thermodynamic calculations, the choice of different equilibrium constant and withal using dimension containing constant usage are an important problem in the field. To overcome these problems, the Modified Langmuir isotherm equilibrium constant is used at determination of thermodynamic parameters. Adsorption mechanism steps were characterized by using FT-IR, SEM, and EDS. The adsorbent is interacted with each metal ions in $\mathrm{HCl}$ solution electrostatic interaction and surface complex formation between the amine groups. The calculation of the thermodynamic parameters using the dimensionless modified Langmuir equilibrium constant calculated more satisfying and more reliable way. All thermodynamic parameters suggested that Pd (II) and Au (III) adsorptions onto TRIS beads was a spontaneous, physisorption.

Keywords: Adsorption; Modified Langmuir; FTIR; polymer; gold; palladium; tris(2aminoethyl) amine 


\section{Introduction}

Precious metals are widely used as catalysts in various industrial, agricultural and medical fields due to their specific physical and chemical properties. The consumption rate of these precious metals worldwide has exceeded the rate of extraction from basic ores due to their low nature and high production costs [1]. For this reason, a significant part of the precious metals used in the world is offered for by recycling [2].

The vast majority of spent electronic circuit boards and honeycomb type auto catalysts containing precious metals such as gold, palladium and platinum are obtained from waste computers and used automotive catalytic converters. In order for these recovery processes to be cost effective, more than $90 \%$ of precious metals must be recovered [3]. Two basic processes are used in platinium group metals and precious metals recovery: hydrometallurgical or pyrometallurgical processes. Hydrometallurgical processes offer an advantage in metal recovery, due to their relatively low cost, less environmental impact (such as free from hazardous gas or dust) and suitable for small-scale applications comparing to pyrometallurgical processes. These features make hydrometallurgical processes potential alternatives for the recovery of precious metals [4]. In an important step of these processes, it is the adsorption of precious metal ions with adsorbents containing suitable functional groups from leach solutions. In this context, it has been reported that polymers containing primary, secondary and tertiary amine groups are used with high adsorption efficiency in the adsorption of various precious metal ions $[5,6]$. That is may be having the capacity of different types of amine functional groups to perform ion exchange and coordination simultaneously under optimum conditions [7]. 
Referring to studies conducted in recent years, the study conducted with 1,2Diaminoethane functionalized Amberlite XAD-4 adsorbent, 14.0 and $31.0 \mathrm{mg} / \mathrm{g} \mathrm{Pd}$ (II) and Au (III) capacity was reported [8]. The adsorption capacities of Pd (II) and Au (III) with the 1,6-Hexaethylenediamine functional group and the styrene / divinylbenzene polymer were found to be 40.0 and $341.0 \mathrm{mg} / \mathrm{g}$, respectively [9]. Zhang at al. [10] obtained an adsorption capacity of $459.29 \mathrm{mg} / \mathrm{g}$ with the 2,6diaminopyridine functionalized PVP polymer with Au (III) chloro complexes. Chemin et al. [11] are reported of Au (III) adsorption with polyamine dendrimer bonded cellulose polymer and 10 times more adsorption than normal cellulose. A capacity value of $943.5 \mathrm{mg} / \mathrm{g}$ was achieved in $\mathrm{Au}$ (III) adsorption with cross-linked polyethylene imine polymer beads [12]. It has also been reported that the polymer has the ability to reduce it into the metallic form. As can be seen, high capacity values from chlorinated complexes of Pd (II) and Au (III) ions can be obtained with amine functionalized polymer adsorbents $[13,14]$. According to Pearson's soft-hard acidbase concept [15], in the TRIS polymer structure to be used in this study, it is thought that having all the different functional amines like $-\mathrm{RNH}_{2},-\mathrm{RNH}$, and $-\mathrm{R}_{3} \mathrm{~N}$ will increase the adsorption capacity.

Since Langmuir isotherm equation was proposed in 1918 to describe gas adsorption onto solid surfaces [16], it has been widely applied from aqueous solutions to adsorption. There are several problems in calculating the equilibrium constant and thermodynamic parameters using Langmuir isotherm, since the effect of solution concentration is neglected in identifying adsorption and desorption events in more condensed phases such as aqueous solutions. According to the Langmuir isotherm, the complete coating of the surface, which meaning single layer adsorption $\left(\mathrm{q}_{\mathrm{e}}=\mathrm{q}_{\mathrm{m}}\right)$ can only realize when $\mathrm{C}_{\mathrm{e}} \rightarrow \infty$. Since the $\mathrm{C}_{e}$ amount at any solution cannot be 
infinite, in the application of Langmuir isotherm equation at liquid phase, saturated solution concentration $\left(\mathrm{C}_{s}\right)$ should be taken into consideration. In this case, in order to achieve monolayer adsorption in a modified Langmuir isotherm $\left(\mathrm{q}_{\mathrm{e}}=\mathrm{q}_{\mathrm{m}}\right)$, the concentration of the solution can be only accour at saturated solution $\left(\mathrm{C}_{\mathrm{e}}=\mathrm{C}_{\mathrm{s}}\right)$. Basing on this basic theoretical knowledge, since the Modified Langmuir isotherm proposed by Azizan et al. [17], and with using this equation, dimensionless Langmuir's equilibrium constant $\left(\mathrm{K}_{\mathrm{ML}}\right)$ has been proposed. This allows us to have a suitable equilibrium constant for use in thermodynamic calculations. In addition, since the proposed isotherm equation is considering desorption events at the equilibrium state, the theoretical basis for adsorption in solution is a more suitable than the Langmuir isotherm equation [17]. In this study, the Modified Lanmuir isotherm equilibrium constant $\left(\mathrm{K}_{\mathrm{ML}}\right)$ is used to calculate thermodynamic parameters.

Here, adsorption of Pd (II) and Au (III), chloro species ions onto commercial TRIS polymer beads would be evaluated. The optimizing parameters such as $\mathrm{pH}$, initial concentration and contact time to adsorptions would be examined. The Modified Langmuir, Redlich-Peterson isotherm equation constants are tried to be calculated by using non-linear regression method in Microsoft Excel Solver Extension. The equilibrium data are fitted into five different isotherms equations to determine the correlation between the isotherm models and experimental data. Pseudo-firstand second-order, intraparticle diffusion and the Elovich equations kinetic equation parameters were calculated for Pd (II) and Au (III) adsorption systems. Furthermore, using the Modified Langmuir isotherm equilibrium constants for each metal ion systems, the thermodynamic parameters, such as Gibbs free energy change $\left(\Delta \mathrm{G}^{\circ}\right)$, enthalpy change $\left(\Delta \mathrm{H}^{\circ}\right)$ and entropy change $\left(\Delta \mathrm{S}^{\circ}\right)$, which have been calculated and discussed. To clarify the interaction mechanism between adsorbate and adsorbent 
surface with instrumental techniques such as FTIR, EDAX were used. SEM images was used to investigate the particle size and morphology of the Tris (2-aminoethyl) amine-bound polystyrene polymer.

\section{Materials and Methods}

\subsection{Materials}

Commercial Tris (2-aminoethyl) bonded polystyrene polymer beads were used as adsorbent in the study. TRIS beads structure consists of 3.5-5.0 mmol / g N loaded, $1 \%$ divinylbenzene cross-linked $\mathrm{N}-\quad\{2-\quad$ [Bis (2-aminoethyl) amino] ethyl $\}$ aminomethyl - polystyrene polymers. TRIS polymer beads was purchased from Alfa Aesar Gmbh (Karlsruhe, Germany). Figure 1 shows the molecular structure of TRIS polymer. In addition, SEM image of TRIS polymer beads can be seen at Figure S5. $\mathrm{Pd}\left(\mathrm{NO}_{3}\right)_{2}$ solution in $0.5 \mathrm{~mol} / \mathrm{L} \mathrm{HNO}_{3}$ and $\mathrm{H}\left(\mathrm{AuCl}_{4}\right)$ solution in $2 \mathrm{~mol} / \mathrm{L} \mathrm{HCl}$ were used for Pd (II) and Au (III) stock solution (Merck KGaA, Darmstadt, Germany). The pHs of the solutions were adjusted with Schott brand CG 840 model pH meter by using $\mathrm{NaOH}$ and $\mathrm{HCl}$ solutions. Weighing measuring OHAUS brand precision scales were used.

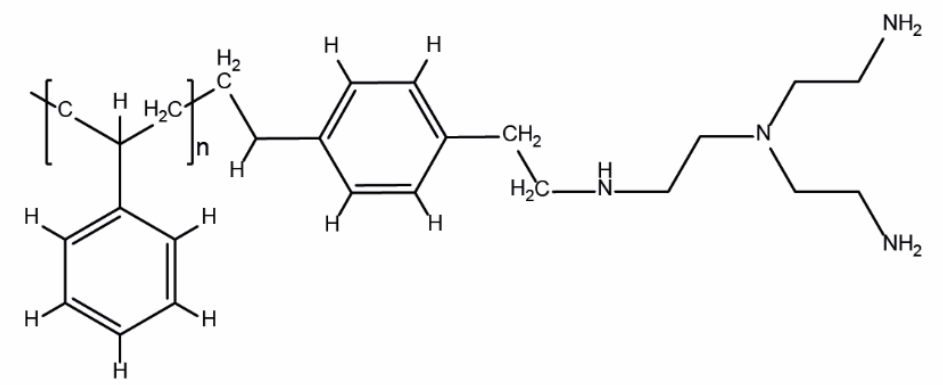

Figure 1. The molecular structure of $1 \%$ divinylbenzene cross-linked $\mathrm{N}-\{2-[\mathrm{Bis}(2-$ aminoethyl)amino] ethyl\}aminomethyl-polystyrene polymer.

$<<$ Figure $1>>$

\subsection{Analytical methods}

FTIR spectra were obtained with Perkin Elmer Spectrum Two spectrophotometer, averaging 10 scans at $4 \mathrm{~cm}^{-1}$ resolution by running in ATR mode. 
The spectras were scanned between 400-4000 $\mathrm{cm}^{-1}$. Both the morphology and structure of the polymer beads were investigated using a JEOL JSM-6060LV SEM. EDS spectra were recorded on Pd and Au surface covered polymer beads to show the presence of Pd (II), $\mathrm{Au}$ (III) and $\mathrm{Cl}^{-}$on the polymer surface.

\subsection{Adsorption experiments}

In order to determine the effect of $\mathrm{HCl}$ concentration on the adsorption capacities of commercial TIRS polymer beads for Pd (II) and Au (III) ions, 4 different concentration points ranging from $10^{-2} \mathrm{M}$ to $3 \mathrm{M}$ were studied. The batch adsorition studies were carried out with $10 \mathrm{mg}$ of TRIS beads with containing $10 \mathrm{mg} / \mathrm{L}$ metal ions at a $50 \mathrm{~mL}$ volume with using orbital shaker for 24 hours. In order to examine the concentration effect, single metal solutions with an initial concentration of 20 to $150 \mathrm{mg} / \mathrm{L}$ were prepared and $10 \mathrm{mg} / \mathrm{L}$ TRIS beads was added and mixed for 24 hours. For the kinetic studies, $100 \mathrm{mg} / \mathrm{L}$ solutions in $500 \mathrm{~mL}$ were prepared under optimum conditions for each metal ion. $25 \mathrm{mg}$ of TRIS polymer was added and $5 \mathrm{~mL}$ of samples were taken from the solutions at various time intervals ranging from 60 to 2880 minutes. Both precious metal concentrations were made using the Shimadzu AA6711F model atomic absorption spectrometer.

\section{Results and discussion}

\subsection{The effect of $\mathrm{HCl}$ concentration}

The effect of $\mathrm{HCl}$ concentration on $\mathrm{Pd}$ (II) and $\mathrm{Au}$ (III) adsorption at the 3, 1, 10$1,10^{-2}, 10^{-3} \mathrm{M} \mathrm{HCl}$ concentrations was studied, and the results illustrated in Figure 2. In our previous Pd (II) adsorption onto the polymer which is containing different functional group $[13,14]$, it was observed that the adsorption efficiency decreased 
when the $\mathrm{HCl}$ concentration decreased to $10^{-2} \mathrm{M}$. Therefore, $\mathrm{HCl}$ concentration range is chosen. It has been reported that adsorption of negatively charged species in Pd (II) and $\mathrm{Au}(\mathrm{III})$ chloro species $\left(\mathrm{PdCl}_{4}{ }^{2-}, \mathrm{PdCl}_{3}{ }^{-}, \mathrm{AuCl}_{4}-\right)$ adsorption will be favorable due to electrostatic interaction $[13,18,19]$. As can be seen in Figure 2, under $0.1 \mathrm{M}$, and $0.01 \mathrm{M} \mathrm{HCl}$ concentrations highest adsorption capacities achieved for Pd (II) and $\mathrm{Au}$ (III) ions, respectively. In these optimum conditions, to predict palladium and gold chloro species, fraction diagrams were drawn by using Hydra\&Medusa software [20]. Figure S1 shown that under these conditions almost each aqueous forms of metal ions are negatively charged state. This seems to be compatible with the literature. In further experiments, $0.1 \mathrm{M}$, and $0.01 \mathrm{M} \mathrm{HCl}$ concentrations were selected as the optimum conditions for Pd (II) and Au (III) adsorptions, respectively.

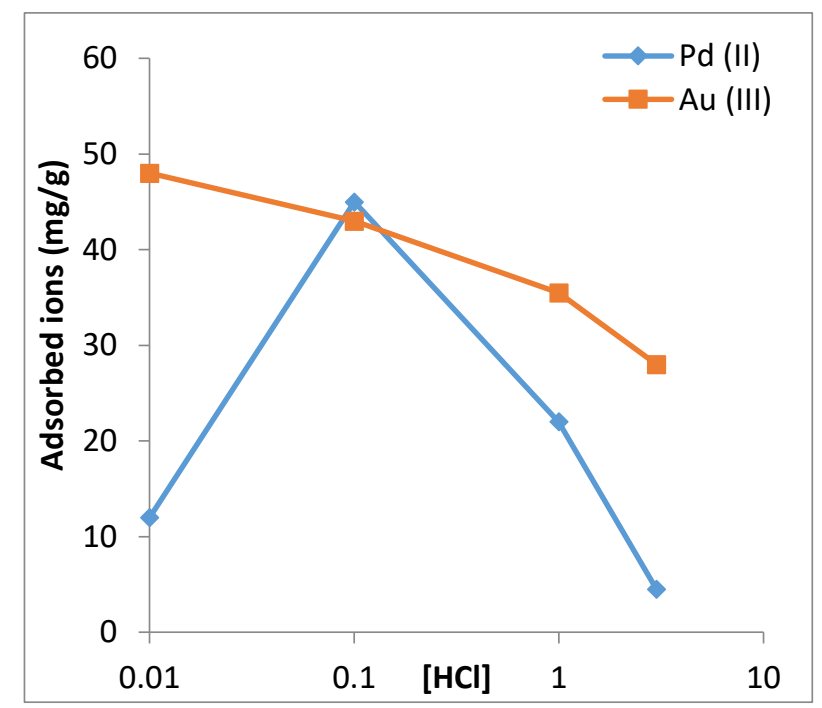

Figure 2. The effects of $\mathrm{HCl}$ concentration on $\mathrm{Pd}(\mathrm{II})$ and $\mathrm{Au}$ (III) adsorption onto TRIS beads $\left(\mathrm{C}_{0}=10 \mathrm{mg} / \mathrm{L}, 293\right.$ $\mathrm{K}, \mathrm{m}=10 \mathrm{mg}, \mathrm{V}=50 \mathrm{ml}, 24$ hours).

\subsection{Adsorption isotherms}

In order to investigate the effect of the initial concentration of Pd (II) and Au (III) solutions on the adsorption yield, the experiments were carried out at different initial metal ion concentrations ranging from 20 to $150 \mathrm{mg} / \mathrm{L}$ in optiumum $\mathrm{HCl}$ concentrations for 24 hours and the results are illustrated in Figure 3. Adsorption 
percentages for Pd (II) and Au (III) ions have changed between 50-81\% and 44-95 \%, respectively. Also, the highest experimental adsorption capacity at $\mathrm{Pd}$ (II) and $\mathrm{Au}$ (III) ions from $150 \mathrm{mg} / \mathrm{L}$ initial concentrations were determined as $187.5 \mathrm{mg} / \mathrm{g}$ and $165.0 \mathrm{mg} / \mathrm{g}$, respectively. For adsorbent consumptions, initial concentrations of 80 $\mathrm{mg} / \mathrm{L}$ and $60 \mathrm{mg} / \mathrm{L}$ are the optimum values for Pd (II) and Au (III) under the studying conditions.

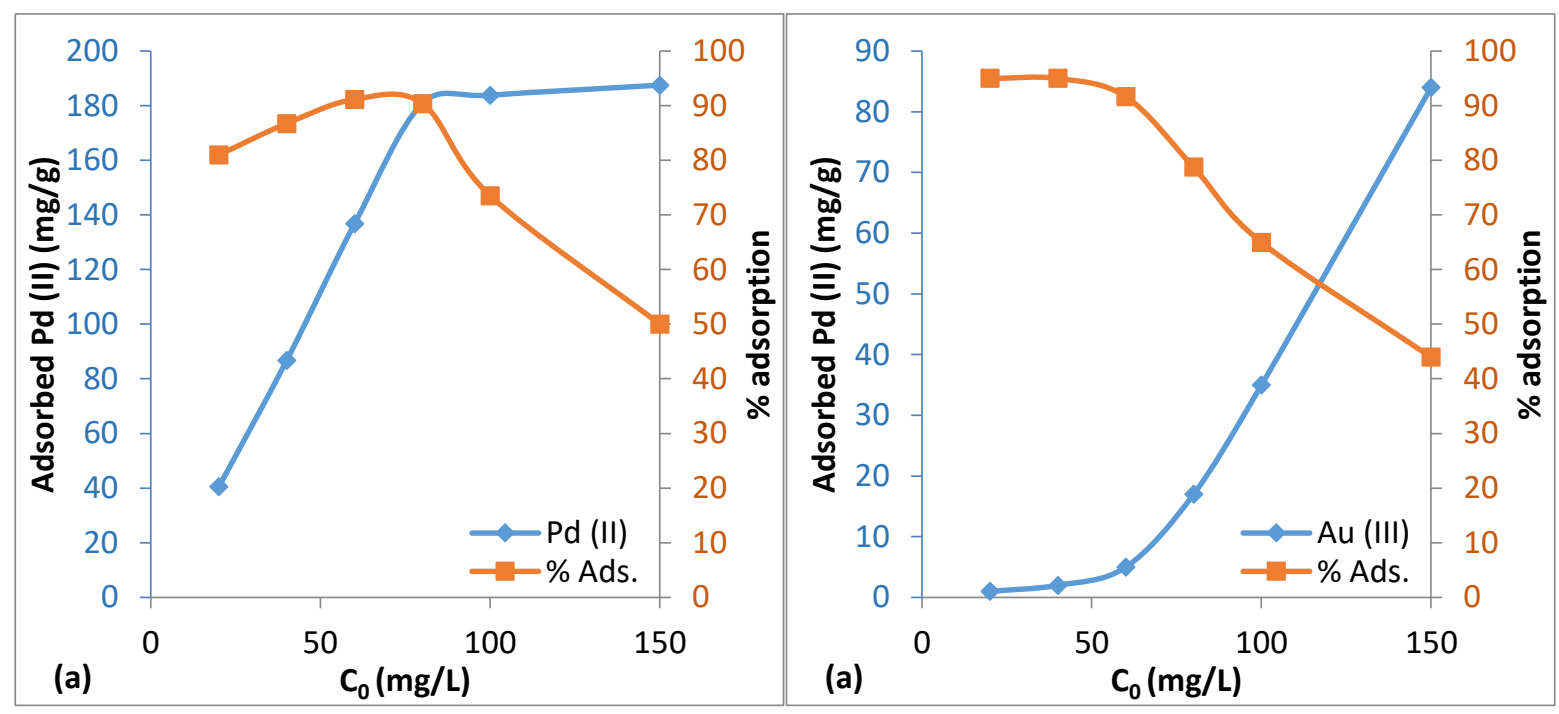

Figure 3. The effects of initial metal ion concentrations to adsorption in Pd (II) (a) and $\mathrm{Au}$ (III) (b) ( $\mathrm{C}_{0}=10-10 \mathrm{mg} / \mathrm{L}, 298 \mathrm{~K}, 10 \mathrm{mg} / 50 \mathrm{ml}$ TRIS polymers, $\mathrm{pH}=2,24$ hours).

\section{$<<$ Figure $3>>$}

$\mathrm{Bu}$ çalışmada gaz fazındaki maddelerin adsorpsiyonu katı yüzeylerdeki adsorpsiyonu için önerilen Langmuir izoterminin yanında, Azizan, Eris ve Wilson tarafında önerilen Modifiye Langmuir izotermi de kullanılmıștır. Bu izotermin en önemli varsayımı çözeltinin konsantrasyonunun denge izotermine etkisinin dikkate alınmasındır. Bilindiği gibi çözeltilerin maksimum içerebileceği çözünen miktarında doygun çözelti oluşmaktadır. Doygunluğa yakın sistemlerdeki adsorpsiyonun karakteristiği ile seyreltik çözeltilerdeki adsorpsiyonun karakteristiğinin aynı olmayacağı düşünülürse, Langmuir sabitleri de değişiklik arz edecektir. Doygun 
çözeltiden adsorpsiyonda, denge durumundaki desoprsiyon hızı ile seyreltik çözeltideki desorpsiyon hızından kimyasal potansiyel farkından dolayı daha düşük olacaktır. Ayrıca adsorpsiyon kinetiğinde de seyreltik ve derişik çözeltiden adsorpsiyonda bütün parametreler aynı olsa da farklılıklar oluşacaktır. Bunun dışında, Langmuir eşitliğinden bulunan $\mathrm{K}_{\mathrm{L}}$ denge sabiti birimsiz olmadığından ve değişik birimler içerebilmesinden dolayı termodinamik parametrelerin hesaplanmasında ancak çok seyreltik çözeltilerden adsorpsiyonda az hata içeren termodinamik parametre sonuçları verebilmekte idi. $\mathrm{Bu}$ eşitlik kullanılarak termodinamik parametrelerin daha doğru bir şekilde hesaplanabilmesi için birimsiz Langmuir denge sabiti hesaplanabilmektedir.

$\mathrm{Bu}$ çalışmadan kullanılan adsorpsiyon izotermleri ve their linear forms Supporting Information dosyasında Table S1'de verilmiştir. Ayrıca karşılaştırma olması bakımından Langmuir izotermi (1) ve modifiye Langmuir izotermi (2) aşağıda verilmiştir:

$q_{e}=\frac{q_{m} K_{L} C_{e}}{1+K_{L} C_{e}}$

$q_{e}=\frac{q_{m} K_{M L} C_{e}}{\left(C_{S}-C_{e}\right)+K_{M L} C_{e}}$

eşitlik (2) de $C_{s}$, adsorpsiyon yapılan maddenin doygun çözelti konsantrasyonudur. Palladium(II) chloride ve Gold(III) chloride çözünürlüğü sırası ile 2418,6 mg/L [21] ve $440157 \mathrm{mg} / \mathrm{L}$ [22] olarak literatürden alınmıştır.

The Langmuir [16], Freundlich [23], Temkin [24], Dubinin-Radushkevich [25,26], and Redlich-Peterson [27] isotherm equations were used to calculate adsorption isotherms at optimum conditions with using the data from Figure 3. These isotherm equations and descriptions are described in the supporting 
information file. Isotherm constants obtained from isotherm calculations, $R^{2}$ values are given in Table $\mathbf{1}$ and Table 2 for Pd (II) and Au (III), respectively. In addition, Langmuir, Freundlich, Tempkin, and Dubinin-Radushkevich isotherms linear form function graphics and their Pearson's correlation coefficient $\left(r^{2}\right)$ values can be seen in Figure S2 and Figure S3. It better to using $\mathrm{r}^{2}$ values for linear regression solves of adsorption equations, whereas, using chi-squared error function, $\mathrm{x}^{2}$, is more suitable for non-linear solves of equations [28,29]. In general, it can be said that Pd (II) adsorption experiments are containing less experimental errors comparing to Au (III) adsorption experiments. In both metal ion adsorptions, Langmuir equation is best representing isotherm among the five equations. Since linear solutions of Modified Langmuir and Langmuir isotherm equations are in the same form, r2 and x2 values are equal (Table S1). According to the non-linear solve of Modified Langmuir equation, the monolayer saturation capacity of Pd (II) and Au (III) ions onto TRIS beads were determined as $206.92 \mathrm{mg} / \mathrm{g}$ and $173.18 \mathrm{mg} / \mathrm{g}$, respectively.

Table 1. Parameters of studied isotherms for Pd (II) adsorption onto TRIS beads (298 K).

\begin{tabular}{|c|c|c|c|c|c|}
\hline Isotherm & $K_{L}$ and $K_{L M}$ & $\mathbf{Q}_{\max }(\mathrm{mg} / \mathrm{g})$ & $\mathbf{R}_{\mathbf{L}}$ & $r^{2}$ & $x^{2}$ \\
\hline Langmuir linear & $30.57 \mathrm{~L} / \mathrm{mg}$ & 205.04 & $0.0428-0.2511$ & 0.9994 & 0.5443 \\
\hline Modified Langmuir linear & 361.62 & 204.47 & & 0.9994 & 0.5443 \\
\hline Modified Langmuir nonlinear & 341.96 & 206.93 & & $0.9964^{*}$ & 0.5465 \\
\hline \multirow{2}{*}{ Freundlich } & $\mathbf{K}_{\mathbf{f}}(\mathrm{L} / \mathrm{g})$ & $\mathbf{n}$ & & $r^{2}$ & $x^{2}$ \\
\hline & 0.0234 & 2.570 & & 0.9259 & 15.36 \\
\hline \multirow[t]{2}{*}{ Tempkin } & $\begin{array}{c}\mathbf{A} \\
(\mathrm{L} / \mathrm{g})\end{array}$ & $\mathbf{B}(\mathrm{j} / \mathrm{mol})$ & & $r^{2}$ & $x^{2}$ \\
\hline & 1.8166 & 40.558 & & 0.9774 & 2.155 \\
\hline \multirow{2}{*}{ Dubinin-Radushkevich } & $\boldsymbol{\beta}(\mathrm{mmol} / \mathrm{j})^{2}$ & $\mathbf{q}_{\mathbf{m}}(\mathrm{mmol} / \mathrm{g})$ & $\mathbf{E}(\mathrm{kJ} / \mathrm{mol})$ & $r^{2}$ & $x^{2}$ \\
\hline & 0.0002 & 1.935 & 56.53 & 0.9983 & 0.3546 \\
\hline \multirow{2}{*}{ Redlich-Peterson } & $\mathbf{K}(\mathrm{L} / \mathrm{g})$ & $\mathbf{a}(\mathrm{L} / \mathrm{mg})$ & $\beta$ & $r^{2 *}$ & $x^{2}$ \\
\hline & 31.26 & 0.1658 & 0.9782 & 0.9957 & 0.4815 \\
\hline
\end{tabular}

$* r^{2}$ are calculated between the measured $\mathrm{q}_{\mathrm{e}}$ and calculated $\mathrm{q}_{\mathrm{e}}$ data values. $<<$ Table $1>>$

The calculated $R_{\mathrm{L}}$ values at different initial metal ion concentrations are shown in Table 1 and Table 2. Dimensionless constant, $R_{\mathrm{L}}$, indicates the shape of the isotherms to be either unfavorable $\left(R_{\mathrm{L}}>1\right)$, linear $\left(R_{\mathrm{L}}=1\right)$, favorable $\left(0<R_{\mathrm{L}}<1\right)$ or 
irreversible $\left(R_{\mathrm{L}}=0\right)$. It was observed that $R_{\mathrm{L}}$ values were determined between 0.0428 - 0.2511 and $0.0735-0.0105$ for Pd (II) and Au (III) species, respectively. This indicated that adsorptions were more favorable for the higher initial ion concentrations than for the lower ones and it takes place spontaneously.

Freundlich isotherm equation derived to describe the adsorption at heterogeneous systems and its formula can be seen at Table S1. In this equation, $1 / \mathrm{n}$ values represents adsorption intensity and surface heterogeneity. When this value closer is to zero, the heterogeneous character of adsorption increases [30,31]. It can be seen at Table 1 and Table 2, Au (III) adsorption is having much heterogeneous nature from Pd (II) adsorption. Where, the adsorption mechanism of gold ions may be take place through several different chloro species.

Table 2. Parameters of studied isotherms for Au (III) adsorption onto TRIS beads (298 K).

\begin{tabular}{|c|c|c|c|c|c|}
\hline Isotherm & $\mathrm{K}_{\mathrm{L}}$ and $\mathrm{K}_{\mathrm{LM}}$ & $\mathbf{Q}_{\max }(\mathrm{mg} / \mathrm{g})$ & $\mathbf{R}_{\mathbf{L}}$ & $r^{2}$ & $x^{2}$ \\
\hline Langmuir linear & $106.2 \mathrm{~L} / \mathrm{mg}$ & 168.54 & $0.0735-0.0105$ & 0.9997 & 7.3206 \\
\hline Modified Langmuir linear & 277401 & 168.54 & & 0.9997 & 7.3206 \\
\hline Modified Langmuir nonlinear & 240692 & 173.18 & & $0.9711^{*}$ & 5.1705 \\
\hline \multirow{2}{*}{ Freundlich } & $\mathbf{K}_{\mathbf{f}}(\mathrm{L} / \mathrm{g})$ & $\mathbf{n}$ & & $r^{2}$ & $x^{2}$ \\
\hline & 0.015 & 4.073 & & 0.7392 & 32.19 \\
\hline \multirow[t]{2}{*}{ Tempkin } & $\begin{array}{c}\mathbf{A} \\
(\mathrm{L} / \mathrm{g})\end{array}$ & $\mathbf{B}(\mathrm{j} / \mathrm{mol})$ & & $r^{2}$ & $x^{2}$ \\
\hline & 17.83 & 25.16 & & 0.8377 & 13.134 \\
\hline \multirow{2}{*}{ Dubinin-Radushkevich } & $\boldsymbol{\beta}(\mathrm{mmol} / \mathrm{j})^{2}$ & $\mathbf{q}_{\mathbf{m}}(\mathrm{mmol} / \mathrm{g})$ & $\mathbf{E}(\mathrm{kJ} / \mathrm{mol})$ & $r^{2}$ & $x^{2}$ \\
\hline & 0.0001 & 1.021 & 81.53 & 0.8753 & 14.71 \\
\hline \multirow{2}{*}{ Redlich-Peterson } & $\mathbf{K}(\mathrm{L} / \mathrm{g})$ & $\mathbf{a}(\mathrm{L} / \mathrm{mg})$ & $\beta$ & $r^{2 *}$ & $x^{2}$ \\
\hline & 77.20 & 0.4336 & 1.000 & 0.9575 & 4.773 \\
\hline
\end{tabular}

$* r^{2}$ are calculated between the measured $\mathrm{q}_{\mathrm{e}}$ and calculated $\mathrm{q}_{\mathrm{e}}$ data values. $<<$ Table 2>>

The Tempkin isotherm equation defined by ignoring in the extremely low and high concentration ranges [32]. The equation is representing better Pd (II) adsortion than Au (III) adsorption onto TRIS beads. Calculated Dubinin-Radushkevich single layer capacities for Pd (II) and Au (III) are $205.91 \mathrm{mg} / \mathrm{g}$ and $201.09 \mathrm{mg} / \mathrm{g}$, repectively. As can be seen, these values are very close to Langmuir single layer capacities for each 
system. In both adsorption, due to the Dubinin-Radushkevich adsorption energy, E, values are higher than $18 \mathrm{kj}$ per mole, it can be said that particle diffusion mechanism is playing important role at adsorption [32]. The Redlich-Peterson isotherm theory covers both Langmuir and Freundlich isotherm assumptions [27]. The $\beta$ isotherm constant can be between $0 \leq \beta \leq 1$ values. Because in each adsorption $\beta$ values close or equal to one value, Langmuir isotherm best representing equation for each adsorptions.

The compliance with the experimental data to the calculated data points from isotherm constants at Table 1 and Table 2 , and in both metal ion adsorptions result is plotted in Figure 4.

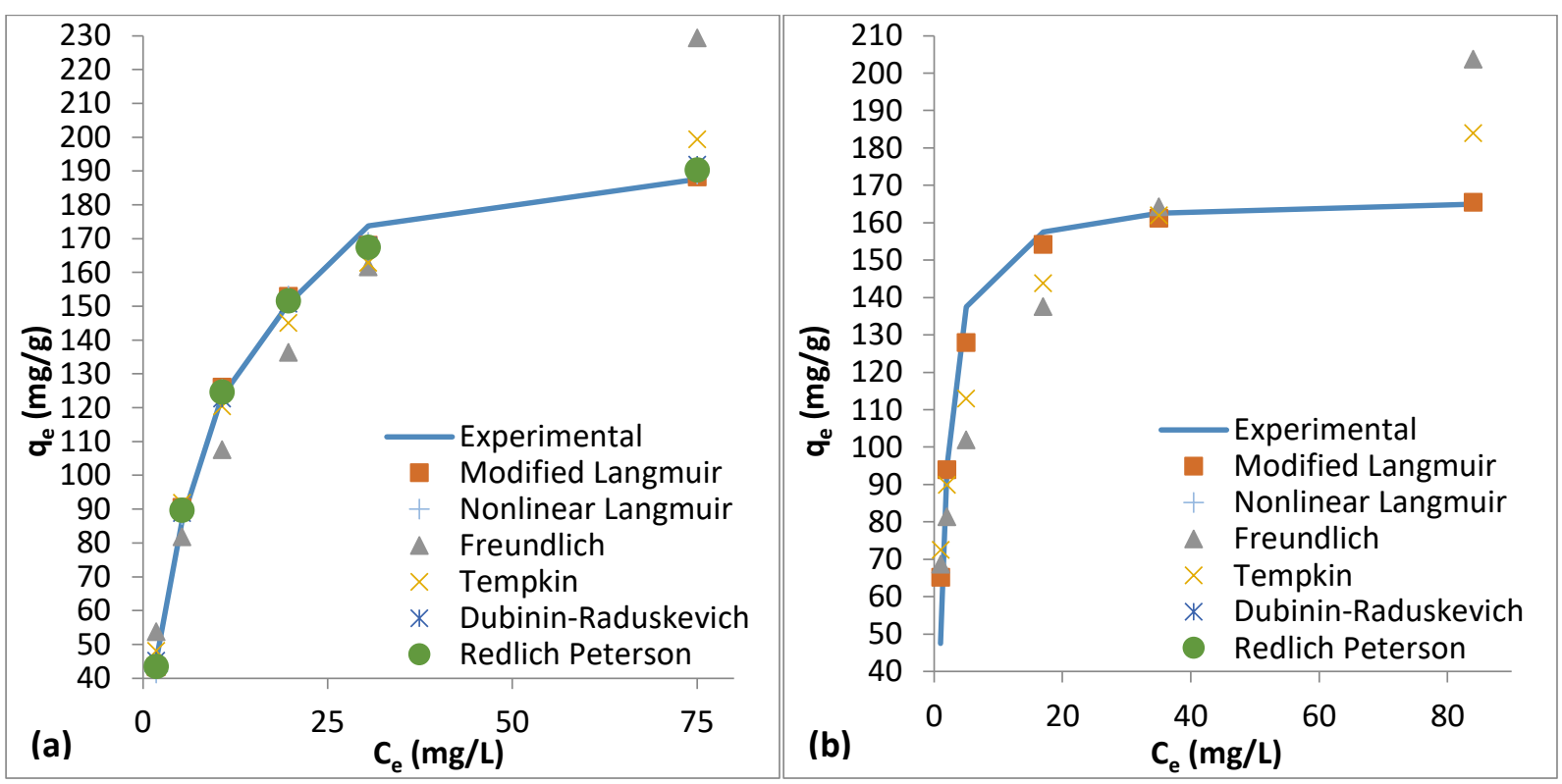

Figure 4. Equilibrium curves for adsorption of $\mathrm{Pd}$ (II) and $\mathrm{Au}$ (III) onto TRIS polymer beads $\left(\mathrm{C}_{0}=20-150 \mathrm{mg}\right.$ $\mathrm{L}^{-1}, 298^{\circ} \mathrm{K}, 24$ h., $25 \mathrm{~mL}, 10 \mathrm{mg}$ adsrobent, $\mathrm{pH} \mathrm{1,} \mathrm{and} \mathrm{2,} \mathrm{respectively).}$

$<$ <igure 4>>

A list of studies with relative amine functional group containing adsorbents, their optimum conditions and obtained maximum capacities has been presented in Table 3. As can be seen, the survey from the literature indicates that most of the optimum conditions reported for palladium and gold ions from $\mathrm{HCl}$ media are 
between pH 4 and pH 1 and 1-24 hour contact time is usually enough time to reach equilibrium. Capacity results obtained from TRIS polymer beads are higher than the most of adsorbents for Pd (II) and Au (III). The adsorption capacity values are obtanined as 206.93 and $171.18 \mathrm{mg} / \mathrm{g}$ for Pd (II) and Au (III) ions, respectively. Hence, the TRIS polymer beads are having high adsorption capacity toward the precious metal ions. To increase the adsorption capacity, it may be beneficial to increase the surface area of TRIS beads by etching surface.

Table 3. Maximum Au (III) adsorption capacities onto various amine type adsorbents

\begin{tabular}{|c|c|c|c|c|}
\hline $\begin{array}{l}\text { Metal } \\
\text { ions }\end{array}$ & $\begin{array}{l}\text { Maximum uptake } \\
(\mathrm{mg} / \mathrm{g})\end{array}$ & $\begin{array}{c}\text { [HCl] } \\
(\mathrm{M})\end{array}$ & $\begin{array}{c}\text { Contact } \\
\text { time } \\
\text { (hour) }\end{array}$ & Adsorbent \\
\hline Pd (II) & 15.29 & $\mathrm{pH} 4$ & $20 \mathrm{~min}$. & Melamine formaldehyde thiourea resin [33] \\
\hline Pd (II) & 158.7 & pH 1 & - & Polyamine Silica Gel [34] \\
\hline Pd (II) & 14.4 & pH 3 & 72 & Theophylline-bearing polystyrene [35] \\
\hline Pd (II) & 191.6 & $0.1 \mathrm{HNO}_{3}$ & 6 & Pyridine based polymer [36] \\
\hline Pd (II) & 10 & 0.5 & 1 & Tri-octyl/decyl amine (Arnberlite XAD2) [37] \\
\hline Pd (II) & 270.5 & 2 & 24 & Silica-Based (Poly)Amine [38] \\
\hline Pd (II) & 43 & 0.1 & 48 & Poly (4-vinylpyridine) resins [39] \\
\hline Pd (II) & 517.2 & pH 2 & 4 & Triazine-hexamine polymer [13] \\
\hline Pd (II) & 7.78 & pH 1.5 & 8 & Modified polyacrylonitrile (PAN)-based [40] \\
\hline Pd (II) & 109.47 & pH 2 & 4 & Lysine modified crosslinked chitosan [41] \\
\hline Pd (II) & 29 & $3 \mathrm{HNO}_{3}$ & 2 & Dithiodiglycolamide impregnated XAD-16 [42] \\
\hline Pd (II) & 9.99 & 0.1 & 4 & Acrylic Amberlyst A-23 resin [43] \\
\hline \multirow[t]{2}{*}{ Pd (II) } & 4.3 & 1 & $30 \mathrm{~min}$. & Polyamine functionalized polystyrene [44] \\
\hline & 52.77 & 1 & 1 & $\begin{array}{l}\text { N-substituted 2- } \\
\text { (diphenylthiophosphoryl)acetamides [45] }\end{array}$ \\
\hline $\mathrm{Pd}(\mathrm{II})$ & 206.93 & 0.1 & 24 & This study \\
\hline $\mathrm{Au}(\mathrm{III})$ & 48.8 & pH 1.5 & 8 & Imidazole functional thiol-ene resin [46] \\
\hline $\mathrm{Au}(\mathrm{III})$ & 3025 & 2 & 8 & Persimmon-formaldehyde resin [47] \\
\hline $\mathrm{Au}(\mathrm{III})$ & 66 & 1 & 48 & Piperazine modified divinylbenzene [48] \\
\hline $\mathrm{Au}(\mathrm{III})$ & 190 & 1 & 48 & Amine modified divinylbenzene copolymers \\
\hline $\mathrm{Au}(\mathrm{III})$ & 443.2 & pH 2 & 3 & Thiirane methacrylate resin [50] \\
\hline $\mathrm{Au}(\mathrm{III})$ & 1325.09 & $\mathrm{pH} 3$ & 5 & Amin magnetic silica gel [51] \\
\hline $\mathrm{Au}(\mathrm{III})$ & 735.3 & 2 & 2 & Imidazolium cellulose microsphere [52] \\
\hline $\mathrm{Au}(\mathrm{III})$ & 537.53 & pH 2.4 & 24 & Aminomethyl pyridine cellulose [53] \\
\hline $\mathrm{Au}(\mathrm{III})$ & 33.48 & 0.1 & 1 & Amberlite XAD-16 [54] \\
\hline $\mathrm{Au}(\mathrm{III})$ & 283.9 & 4 & $300 \mathrm{~min}$. & $\begin{array}{l}\text { Mercaptothiadiazole functionalized } \mathrm{Ni}_{0.6} \mathrm{Fe}_{2.4} \mathrm{O}_{4} \\
{[55]}\end{array}$ \\
\hline $\mathrm{Au}(\mathrm{III})$ & 3257.3 & pH 3-5 & 72 & Thiourea-grafted electrospun polyacrylonitrile \\
\hline $\mathrm{Au}(\mathrm{III})$ & 43 & 0.1 & 81 & Poly (4-vinylpyridine) resins [39] \\
\hline $\mathrm{Au}(\mathrm{III})$ & 1086 & pH 2 & 24 & Triazine-polyamine polymer [14] \\
\hline $\mathrm{Au}(\mathrm{III})$ & 70.34 & $\mathrm{pH} 2$ & 4 & Lysine modified crosslinked chitosan [41] \\
\hline $\mathrm{Au}(\mathrm{III})$ & 173.18 & 0.01 & 24 & This study \\
\hline
\end{tabular}

$<<$ Table $2>>$

\subsection{Adsorption Kinetics}


The effect time to Pd (II) and Au (III) adsorption on TRIS polymer beads in optimum conditions was examined and the results are given in Figure 5 . In the adsorption kinetics experiments, both metal ions exhibited slow adsorption rates at the 10 hours of contact with each metal ions and this leading moderate kinetic constant values ( $\mathrm{k}_{1}$ and $\mathrm{k}_{2}$, etc).

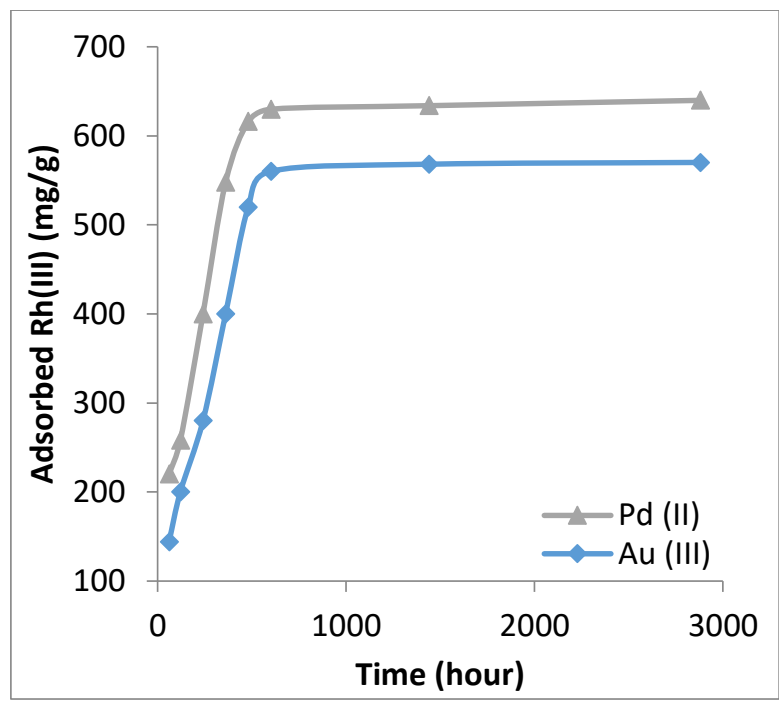

Figure 5. The effects of contact time to Pd (II) and Au (III) adsorptions onto TRIS beads ( $\mathrm{C}_{0}=100 \mathrm{mg} / \mathrm{L}, 298 \mathrm{~K}, 48$ h., 25mg TAPEHA /500ml, pH 1, and 2, respectively).

$<<$ Figure $5>>$

With the development of the adsorption equilibrium theory on heterogeneous solid surfaces, the development of the kinetic adsorption-desorption theory has has also progressed. An adsorption-desorption kinetics can include the following four steps: external diffusion from solution to interface, diffusion into pores, diffusion of molecules on surface, and realization of adsorption-desorption process $[57,58]$. In order to understand time depended behavior of adsorption process, five commonly used models, pseudo first- [59] and second-order [60] equation, intraparticle diffusion [61] equation and the Elovich [62,63] equation, were used for both metal ion adsorptions. Detailed informations can be found at the supporting informations. 
Here, the kinetics data were fitted with models and the model parameters are presented in Table 3. Further, graphical solve lines of these kinetic functions and their $R^{2}$ values can be seen in Figure S4. The calculated kinetic constants and $R^{2}$ values are given in Table 4 . When the closer $\mathrm{R}^{2}$ value is to one, it will show that equation could adequately represents the experimental adsorption process [28]. In both adsorption metal adsorption, the pseudo-second-order model was the better fitting model among to studied four models. For each metal adsorption kinetics, the experimental capacity values doesn't matches with the qe value of pseudo second order model (q2) at the studied initial concentration of $100 \mathrm{mg} / \mathrm{L}$. the pseudo first order model performing worst $\mathrm{q}_{1}$ value fitting wit $\mathrm{q}_{\mathrm{e}}$, as expected.

Table 4. Kinetic parameters for adsorption of Pd (II) and Au (III) ions onto TRIS beads.

\begin{tabular}{|c|c|c|c|c|c|c|c|}
\hline \multirow[b]{2}{*}{$\begin{array}{l}\text { Metal } \\
\text { ion }\end{array}$} & \multirow[b]{2}{*}{$\begin{array}{c}\boldsymbol{q}_{\mathbf{e}, \mathbf{e x p}} \\
(\mathrm{mg} / \mathrm{g})\end{array}$} & \multicolumn{3}{|c|}{ First-order kinetic equation } & \multicolumn{3}{|c|}{ Second-order kinetic equation } \\
\hline & & $\mathbf{q}_{1}(\mathrm{mg} / \mathrm{g})$ & $\mathbf{k}_{1}(1 / \min )$ & $R^{2}$ & $\mathbf{q}_{2}(\mathrm{mg} / \mathrm{g})$ & $\begin{array}{c}\mathbf{k}_{\mathbf{2}} \\
\text { (g/ } \\
\text { (mg.min.)) }\end{array}$ & $R^{2}$ \\
\hline Pd (II) & 640 & 363.5 & 0.0035 & 0.7825 & 713.3 & 0.000010 & 0.9866 \\
\hline $\mathrm{Au}(\mathrm{III})$ & 570 & 509.0 & 0.0042 & 0.9056 & 684.0 & 0.000006 & 0.9729 \\
\hline \multirow{2}{*}{$\begin{array}{l}\text { Metal } \\
\text { ion }\end{array}$} & \multirow[b]{2}{*}{$\begin{array}{c}\boldsymbol{q}_{\mathbf{e}, \mathbf{e x p}} \\
(\mathrm{mg} / \mathrm{g})\end{array}$} & \multicolumn{3}{|c|}{ The Elovich equation } & \multicolumn{3}{|c|}{ Intraparticle diffusion equation } \\
\hline & & $\begin{array}{c}\boldsymbol{\alpha} \\
\left(\mathrm{mg}^{-1} \cdot \mathrm{min}^{-1}\right)\end{array}$ & $\begin{array}{c}\boldsymbol{\beta} \\
\left(\mathrm{mg} \cdot \mathrm{g}^{-1}\right)\end{array}$ & $\boldsymbol{R}^{2}$ & (mg.g & $\left(n .^{-1 / 2}\right)$ & $R^{2}$ \\
\hline $\mathrm{Pd}(\mathrm{II})$ & 640 & 15.596 & 0.0079 & 0.8077 & & & 0.8789 \\
\hline $\mathrm{Au}(\mathrm{III})$ & 570 & 7.361 & 0.0078 & 0.8467 & & & 0.9501 \\
\hline
\end{tabular}

\section{$<<$ Table 4>>}

Figure 6 illustrates fitting calculated qe values using kinetic constants at Table 3 to the experimental data points for both adsorption. As can be seen, the pseudo second-order kinetic equation is representing adsorption kinetic well for each system. As many precious metal ion adsorption studies $[8,10,34,44,46,51,55]$, Kanagare et al. studied Pd (II) adsorption onto commercial dithio diglycolamide impregnated XAD-16, it is represented better by a pseudo second order kinetics equation [42]. At high initial concentrations, the deviations in the intraparticle diffusion calculated qe values is very high. 


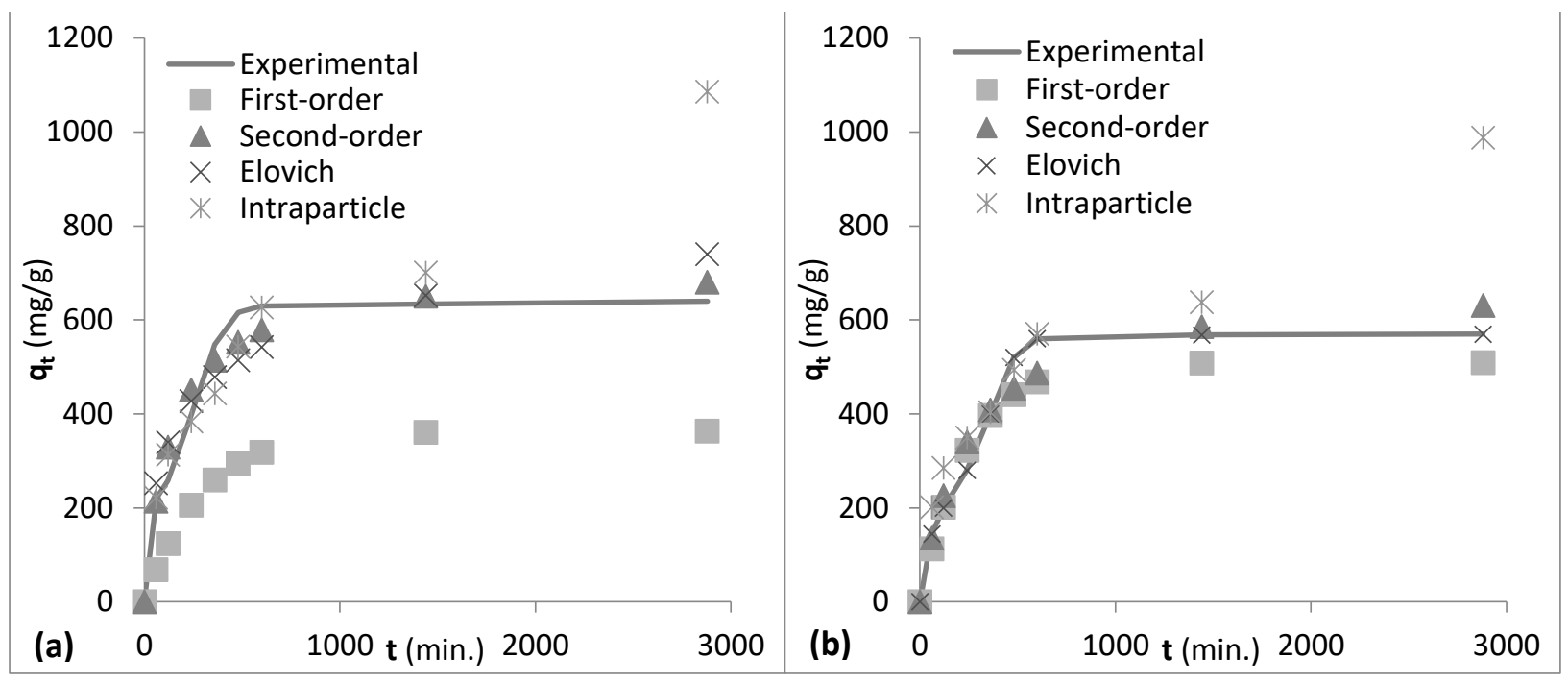

Figure 6. The measured and modeled time profiles for adsorption of the Pd (II), (a) and Au (III), (b) onto TRIS beads ( $\mathrm{C}_{0}=100 \mathrm{mg} / \mathrm{L}, 298 \mathrm{~K}, 24$ h., 25mg TAPEHA /500ml, pH 1, and 2, respectively).

$<<$ Figure 6 $>>$

\subsection{Temperature Effects}

To understand effects of temperature to Pd (II) and Au (III) adsorption onto TRIS polymer beads, experiments were performed at 298, 308, 318 and $328 \mathrm{~K}$ temperatures for 24 hours and the results are shown in Figure 7. As can be seen, the Pd (II) adsorption capacity decreases with increasing temperature. Despite that, the $\mathrm{Au}$ (III) adsorption capacity increases with temperature. For instance, for initial Pd (II) ion concentration of $100 \mathrm{mg} / \mathrm{L}$, when increasing temperature from 298 to $328{ }^{\circ} \mathrm{K}$, the adsorption capacity value decreases $173.75 \mathrm{mg} / \mathrm{g}$ to $165.50 \mathrm{mg} / \mathrm{g}$. Contrary to, with increasing temperature, Au (III) adsorption capacity increases $162.50 \mathrm{mg} / \mathrm{g}$ to $203.50 \mathrm{mg} / \mathrm{g}$. 


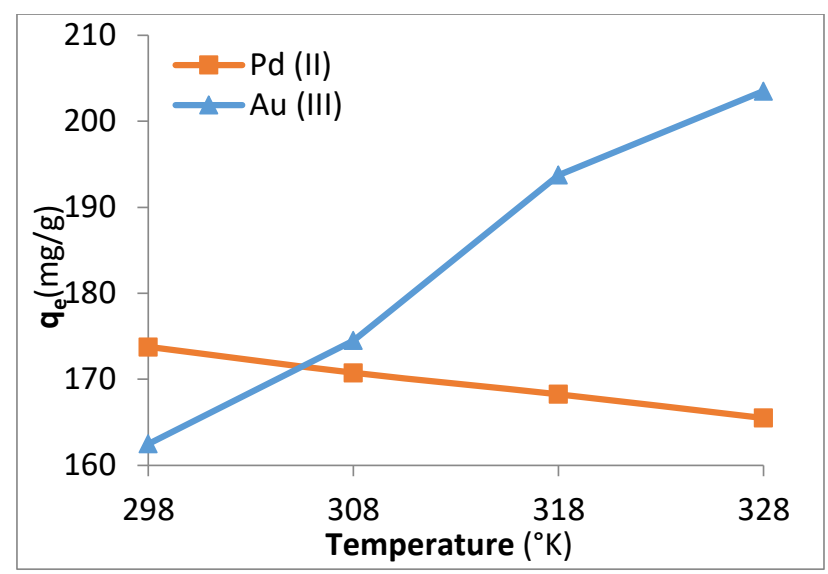

Figure 7. Effect of temperature on Pd (II) and Au (III) adsorption onto TRIS beads (24 hours, $25 \mathrm{~mL}, 10 \mathrm{mg}$ TIRS, pH 1, and 2, respectively).

$<<$ Figure $7>>$

$\ll$ Thermodynamic parameters and comments about it[17].

It is known that Langmuir equilibrium constant has a dimensional parameter at its origin. Moreover, since the units of these parameters vary, the thermodynamic parameters obtained often give different values even for the same system. This problem makes it almost impossible to compare the obtained thermodynamic parameters. Other than this, thermodynamic parameters to be calculated using the experimental equilibrium constant which is contain an acceptable error only if solution concentrations very dilute. Consequently, it is not appropriate to use traditional methods in hetorogen adsorption from solution systems. For the reasons mentioned above, the dimensionless equilibrium constant, $\mathrm{K}_{\mathrm{ML}}$, of the Modified Langmuir isotherm proposed by Azizian et al. [17] was used at the thermodynamic calculations.

The van't Hoff plot for the adsorption of studied metal ions is given in Figure S5 and calculated thermodynamic parameters are tabulated in Table 5. As can be seen, the negative $\Delta G^{0}$ values at any temperature indicates that adsorption occurs spontaneously. 
Generally when $\Delta H^{0}$ value if it smaller than $80 \mathrm{~kJ} / \mathrm{mol}$, this interaction assumed as weak interaction or physisorption. While, the ranges of chemical sorption heat falls into 80-200 kJ/mol range[58]. $\Delta H^{0}$ values for $\mathrm{Pd}$ (II) and $\mathrm{Au}$ (III) adsorption determined as $-1.64 \mathrm{~kJ} / \mathrm{mol}$ and $40.50 \mathrm{~kJ} / \mathrm{mol}$, respectively. Based on this, in all metal ion-bead adsorptions were physisorption process. For the Pd (II) adsorption, the positive $\Delta S^{0}$ values $\left(43.47 \mathrm{~J} \cdot \mathrm{mol}^{-1} \cdot \mathrm{K}^{-1}\right.$ ) suggests randomness is increased during adsorption. Contrary to, $\Delta S^{0}$ value of the $\mathrm{Au}$ (III) adsorption onto TRIS beads calculated as $-31.80 \mathrm{~J} \cdot \mathrm{mol}^{-1} \cdot \mathrm{K}^{-1}$. Randomness is decreased during the adsorption. As can be seen from Table 5 , the $\Delta G^{0}$ value was negative, meaning the feasible and spontaneous nature of metal ions adsorption on TRIS polymer beads.

Table 5. Thermodynamic parameters for the adsorption of Pd (II) and Au (III) ions onto TRIS polymer beads.

\begin{tabular}{|c|c|c|c|c|c|c|}
\hline & \multirow{2}{*}{$\begin{array}{c}\Delta \mathbf{H}^{\mathbf{o}} \\
\left(\mathrm{kJ} \cdot \mathrm{mol}^{-1}\right)\end{array}$} & \multirow{2}{*}{$\begin{array}{c}\Delta \mathbf{S}^{\mathbf{o}} \\
\left(\mathrm{J} \cdot \mathrm{mol}^{-1} \cdot \mathrm{K}^{-1}\right)\end{array}$} & \multicolumn{4}{|c|}{$\Delta \mathbf{G}^{\mathbf{o}}\left(\mathrm{kj} \cdot \mathrm{mol}^{-1}\right)$} \\
\hline & & & $298^{\circ} \mathrm{K}$ & $313^{\circ} \mathrm{K}$ & $333^{\circ} \mathrm{K}$ & $353 \circ \mathrm{K}$ \\
\hline Pd (II) & -1.64 & 43.47 & -14.5943 & -15.0331 & -15.4662 & -15.8980 \\
\hline Au (III) & -40.50 & -31.80 & -31.0520 & -30.6283 & -30.4043 & -30.0708 \\
\hline
\end{tabular}

\subsection{Adsorption Mechanism}

After adsorption, SEM micrographs and EDS spectras are shown in Figure $8(\mathrm{a}, \mathrm{b}, \mathrm{c}, \mathrm{d})$. Surfaces of beads almost fully coved with adsorbed Pd (II) and Au (III) ions (Figure 8 a, b). The weight percentage amount of the $\mathrm{Au}$ (III) ions is higher than Pd (II) ions. This result is compatible with the experimental adsorption capacities. In Au (III) adsorption, chlorine ions are found much than Pd (II) adsorption on the surface. Based on this the adsorption took place over high chlorine ion containing Au (III) complexes. 

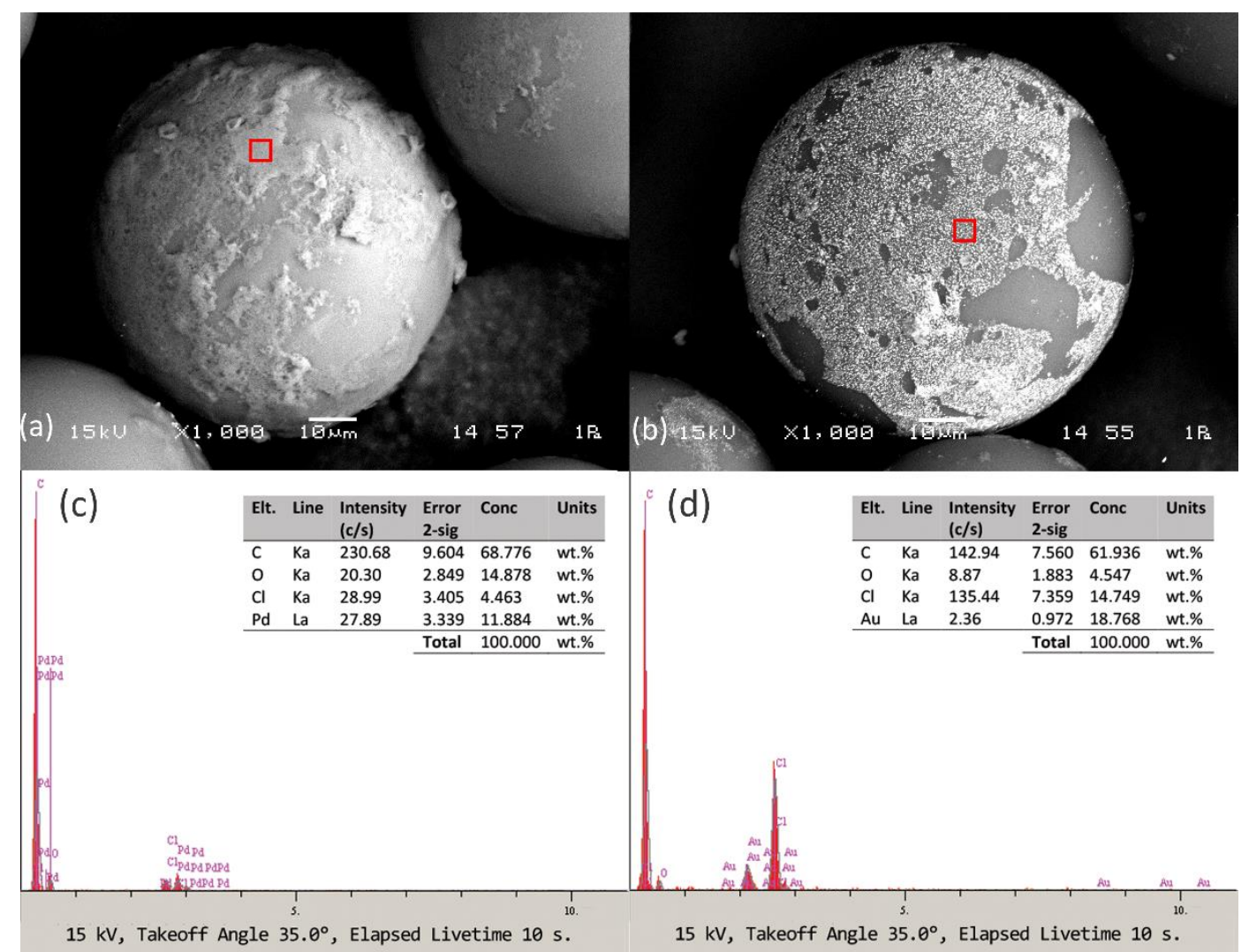

Figure 8. SEM micrograph of Pd (II), (a) and Au (III), (b) adsorbed TRIS beads. Selected area EDS spectra of palladium adsorbed (a) and gold adsorbed surfaces. $<<$ Figure $8>>$

Characteristic FTIR bands of TRIS polymer beads and, the corresponding vibrations before - after adsorption and after being reused were shown in Table 4 . FTIR spectra of TRIS, Pd (II) adsorbed TRIS, Au (III) adsorbed TRIS beads are shown in Figure 9. As can be seen, the characteristic peaks of divinyl benzene in the 845, 900 and $985 \mathrm{~cm}^{-1}$ bands [64] are weakly visible in the spectrum (Figure 9). Due to, it is used small amount like $1 \%$ by weight for cross-linking. 


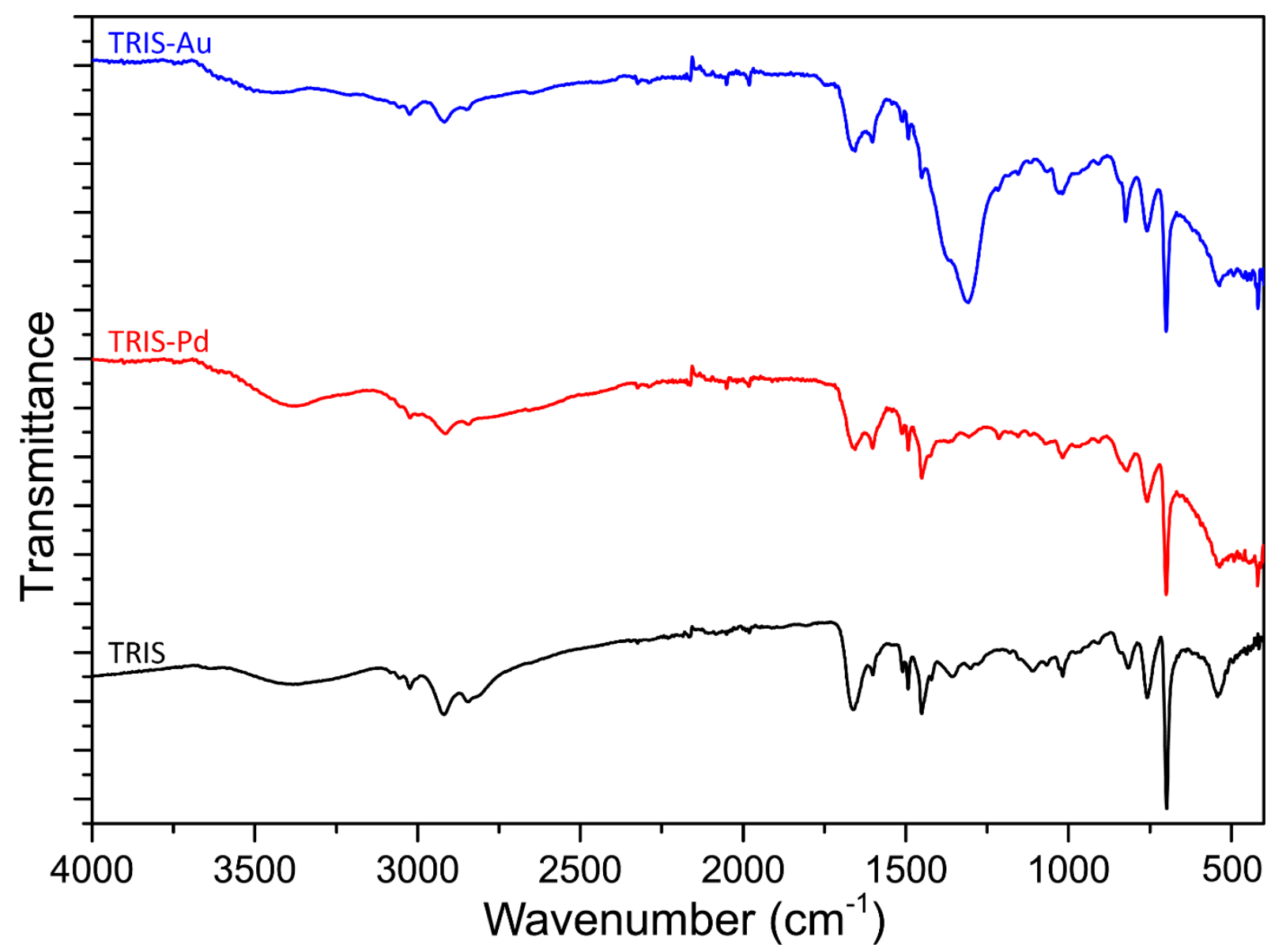

Figure 9. FTIR spectra of TRIS, Pd (II) adsorbed TRIS, Au (III) adsorbed TRIS beads. $<<$ Figure $9>>$

Table 4. Spectral assignments of fresh, Rh(III) adsorbed and recycled TAPEHA

\begin{tabular}{|c|c|c|c|c|c|}
\hline \multirow[b]{2}{*}{$\begin{array}{l}\text { IR } \\
\text { peak }\end{array}$} & \multicolumn{3}{|c|}{ TRIS bands $\left(\mathrm{cm}^{-1}\right)^{a}$} & \multirow[t]{2}{*}{ Assignments $^{\mathbf{b}}$} & \multirow[t]{2}{*}{ Ref. } \\
\hline & $\begin{array}{l}\text { Fresh } \\
\text { polymer }\end{array}$ & $\begin{array}{l}\text { Pd (II) } \\
\text { Adsorbed }\end{array}$ & $\begin{array}{l}\text { Au (III) } \\
\text { Adsorbed }\end{array}$ & & \\
\hline 1 & - & 418 & 418 & $v($ Metal-Cl $)$ & [44] \\
\hline 2 & 543 & 535 & 535 & $v(\mathrm{C}-\mathrm{C}) /(\mathrm{C}=\mathrm{C})$ benzene & [65] \\
\hline 3 & 699 & 700 & 700 & $\begin{array}{l}v(\mathrm{C}-\mathrm{C}) /(\mathrm{C}=\mathrm{C}) \text { benzene, } \\
d_{\mathrm{op}}(\mathrm{CH})\end{array}$ & {$[64,65]$} \\
\hline 4 & 758 & 758 & 758 & $v(\mathrm{C}-\mathrm{C}) /(\mathrm{C}=\mathrm{C})$ benzene & {$[65]$} \\
\hline 5 & 817 & 820 & 825 & $d_{\mathrm{op}}(\mathrm{CH}) \cdot v(\mathrm{CN})$ & {$[44,64,66]$} \\
\hline 6 & 1018 & 1018 & 1022 & $d_{\mathrm{ip}}(\mathrm{CH})$ & [64] \\
\hline 7 & 1110 & - & - & $d_{\mathrm{ip}}(\mathrm{CH}), v(\mathrm{CN})$ & {$[64,66]$} \\
\hline 8 & - & 1214 & 1216 & $d_{\mathrm{ip}}\left(\mathrm{CH}_{2}-\mathrm{Cl}\right)$ & {$[44]$} \\
\hline 9 & 1301 & 1301 & - & $d_{\mathrm{ip}}(\mathrm{CH})$ & [64] \\
\hline 10 & - & - & 1308 & & \\
\hline 11 & 1355 & - & - & $v(-\mathrm{N}-\mathrm{H})$ & [67] \\
\hline 12 & 1451 & 1451 & 1451 & $\begin{array}{l}\mathrm{d}_{\mathrm{ip}}\left(-\mathrm{CH}_{2}-\right) \text { benzene, } \\
d_{\mathrm{ip}}\left(\mathrm{CH}_{2}\right)\end{array}$ & {$[65,68]$} \\
\hline 13 & 1493 & 1493 & 1493 & $v(-\mathrm{CH}-)$ benzene & [65] \\
\hline 14 & 1602 & 1602 & 1602 & $d_{\text {ip }}(-\mathrm{CH}-)$ benzene & [65] \\
\hline 15 & 1662 & 1654 & 1655 & $v(\mathrm{C}=\mathrm{C}), d(\mathrm{~N}-\mathrm{H})$ & {$[44,64]$} \\
\hline 16 & 2845 & 2843 & 2843 & $\mathrm{~d}_{\mathrm{ip}}(\mathrm{NH}), v(\mathrm{CN})$ & [65] \\
\hline 17 & 2918 & 2916 & 2917 & $v_{\mathrm{p}}\left(-\mathrm{CH}_{2}-\right)$ benzene & [65] \\
\hline 18 & 3024 & 3024 & 3024 & $v(\mathrm{CH})$ & [65] \\
\hline
\end{tabular}


a Estimated uncertainty $= \pm 2 \mathrm{~cm}^{-1}$

antisymmetric

b $v=$ stretching, $d=$ deformation, ip $=$ in plane, op = out of plane, $t=$ torsion. The contribution to IR intensities and frequencies were written highest to lowest

\section{$<<$ Table 4>>}

The resulting peaks at $418 \mathrm{~cm}^{-1}$ at metal adsorbed TRIS spectrums is characteristic of $v(\mathrm{Pd}-\mathrm{Cl})$ and $v(\mathrm{Au}-\mathrm{Cl})$, and another peak at 1214 and $1216 \mathrm{~cm}^{-1}$ at TRIS-Pd and TRIS-Au spectra, respectively, which can be assigned to the non-planar wagging of $\mathrm{CH}_{2}$ in $\mathrm{CH}_{2} \mathrm{Cl}$ [44]. This another peaks are not significant peaks. As a difference from TRIS-Pd spectra, a wide and strong peak was formed between 1400 $1200 \mathrm{~cm}$ in gold adsorbed TRIS spectra. This is a characteristic effect of Au (III) adsorption [14]. The weakening and shifting peak at $3384 \mathrm{~cm}^{-1}$ and $1662 \mathrm{~cm}^{-1}$ for $v(\mathrm{C}=\mathrm{C}), d(\mathrm{~N}-\mathrm{H})$ shows that adsorption takes place with amine-functional groups of TRIS polymers. The proposed Pd (II) and Au (III) mechanism are shown in Figure 10. Adsorbed $\mathrm{Pd}$ (II) and Au (III) ions are existing as $\mathrm{PdCl}_{2} \mathrm{~N}_{2}{ }^{2-}$ and $\mathrm{AuCl}_{2} \mathrm{~N}_{2}{ }^{-}$complex forms, respectively.

\section{(a)- Mechanism of Pd (II) species onto TRIS beads}
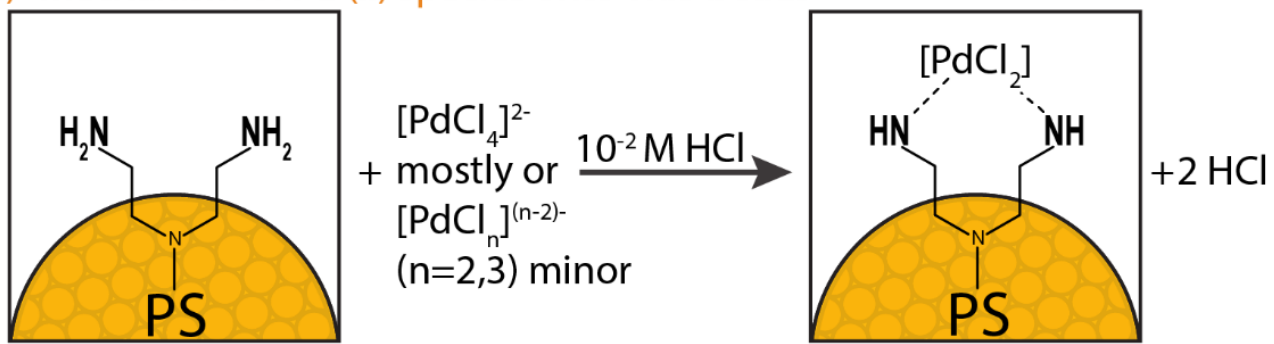

(b)- Mechanism of Au (III) species onto TRIS beads

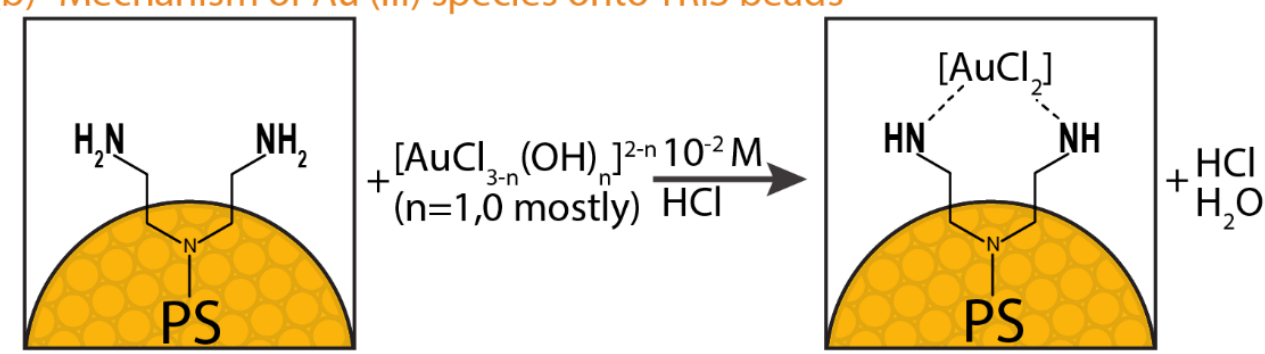


Figure 10. Proposed Pd (II) and Au (III) species adsorption mechanism onto TRIS beads.

\section{$<<$ Figure $10>>$ Adsorption mechanism}

\section{Conclusions}

In the present work, TRIS polymer beads employed as an adsorbent in batch adsorption technique for $\mathrm{Pd}$ (II) and $\mathrm{Au}$ (III) ions from $\mathrm{HCl}$ containing solutions. Optimum conditions for adsorption of Pd (II) and $\mathrm{Au}$ (III) ions were determined as 0.1 $\mathrm{M}$ and $0.01 \mathrm{M} \mathrm{HCl}$, respectively. The Modified Langmuir isotherm, which was proposed recently, was used in calculations and results are compared. The maximum adsorption capacity of TRIS beads were determined to be $204.47 \mathrm{mg} / \mathrm{g}$ for Pd (II), and $168.54 \mathrm{mg} / \mathrm{g}$ for $\mathrm{Au}$ (III), respectively. In both adsorption, kinetics are fitting the pseudo second-order kinetic model. In order to solve the problems arising from the use of $\mathrm{K}$ constant in different units, dimensionless KML constants calculated and nature of adsorption determined. FTIR, and EDS measurements indicate that, after the ionic interaction, surface complexation take places during each metal adsorption on TRIS beads. Finally, TRIS polymer beads could be a promising precious metal ions adsorbent in acidic chloride media for its high adsorption capacity, and durability.

\section{Supplementary Material}

See supplementary material for used theoretical explanation about adsorption isotherms and kinetic equations, calculated equation parameters, and speciation of Pd (II) and Au (III) ions under optimum experimental conditions.

\section{Funding Sources}

This study was supported by the Scientific Research Projects Commission of Sakarya University under the contract number 2016-34-08-004.

\section{Author Contributions}


M.I. proposed the project. M.I. and M.C. designed the experimental studies. M.Ö. made laboratory studies. M.C. carried out the calculations and assembled the data, and wrote the manuscript. 


\section{REFERENCES}

[1] H. Kasaini, M. Goto, S. Furusaki, Selective separation of Pd(II), Rh(III), and Ru(III) ions from a mixed chloride solution using activated carbon pellets, Sep. Sci. Technol. 35 (2000) 1307-1327. doi:10.1081/SS-100100226.

[2] L. Wang, K. Wang, R. Huang, Z. Qin, Y. Su, S. Tong, Hierarchically flower-like WS2 microcrystals for capture and recovery of Au (III), Ag (I) and Pd (II), Chemosphere. 252 (2020). doi:10.1016/j.chemosphere.2020.126578.

[3] S. Shen, T. Pan, X. Liu, L. Yuan, Y. Zhang, J. Wang, et al., Adsorption of Pd(II) complexes from chloride solutions obtained by leaching chlorinated spent automotive catalysts on ion exchange resin Diaion WA21J, J. Colloid Interface Sci. 345 (2010) 12-18. doi:10.1016/j.jcis.2010.01.049.

[4] A. Tuncuk, V. Stazi, A. Akcil, E.Y. Yazici, H. Deveci, Aqueous metal recovery techniques from e-scrap: Hydrometallurgy in recycling, Miner. Eng. 25 (2012) 28-37. doi:10.1016/j.mineng.2011.09.019.

[5] B. Fotoohi, L. Mercier, Some insights into the chemistry of gold adsorption by thiol and amine functionalized mesoporous silica in simulated thiosulfate system, Hydrometallurgy. 156 (2015) 28-39. doi:10.1016/j.hydromet.2015.05.010.

[6] J. Kwame, S. Lin, A. Kumar, Y. Zhao, J. Choi, M. Song, et al., Benignly-fabricated crosslinked polyethylenimine/calcium-alginate fibers as high-performance adsorbents for effective recovery of gold, J. Clean. Prod. 252 (2020) 119389. doi:10.1016/j.jclepro.2019.119389.

[7] P. Cyganowski, Synthesis of Adsorbents with Anion Exchange and Chelating Properties for Separation and Recovery of Precious Metals-A Review, Solvent Extr. Ion Exch. 38 (2020) 143-165. doi:10.1080/07366299.2020.1720117. 
[8] P. Cyganowski, K. Garbera, A. Leśniewicz, J. Wolska, P. Pohl, D. JermakowiczBartkowiak, The recovery of gold from the aqua regia leachate of electronic parts using a core-shell type anion exchange resin Recovery of gold from the aqua regia leachate of electronic parts, J. Saudi Chem. Soc. 21 (2017) 741-750. doi:10.1016/j.jscs.2017.03.007.

[9] D. Jermakowicz-Bartkowiak, P. Cyganowski, Effect of Microwave Radiation on the Synthesis of Ion Exchange Resins: A Comparative Study, Solvent Extr. Ion Exch. 33 (2015) 510-521. doi:10.1080/07366299.2015.1046301.

[10] B. Zhang, S. Wang, L. Fu, L. Zhang, J. Zhao, C. Wang, Selective high capacity adsorption of $\mathrm{Au}(\mathrm{III})$ from aqueous solution by poly(glycidyl methacrylate) functionalized with 2,6-diaminopyridine, Polym. Bull. 76 (2019) 4017-4033. doi:10.1007/s00289-0182594-5.

[11] M. Chemin, C. Moreau, B. Cathala, A. Villares, Adsorption behavior of reducing endmodified cellulose nanocrystals: A kinetic study using quartz crystal microbalance, J. Renew. Mater. 8 (2020) 29-43. doi:10.32604/jrm.2020.07850.

[12] F. Liu, L. Zhou, W. Wang, G. Yu, S. Deng, Adsorptive recovery of Au(III) from aqueous solution using crosslinked polyethyleneimine resins, Chemosphere. 241 (2020). doi:10.1016/j.chemosphere.2019.125122.

[13] M. Sayın, M. Can, M. İmamoğlu, M. Arslan, 1,3,5-Triazine-pentaethylenehexamine polymer for the adsorption of palladium (II) from chloride-containing solutions, React. Funct. Polym. 88 (2015) 31-38. doi:10.1016/j.reactfunctpolym.2015.02.003.

[14] M. Can, M. Doğan, M. İmamoğlu, M. Arslan, Au (III) uptake by triazine polyamine polymers: Mechanism, kinetic and equilibrium studies, React. Funct. Polym. 109 (2016). doi:10.1016/j.reactfunctpolym.2016.10.009.

[15] R.G. Pearson, Recent advances in the concept of hard and soft acids and bases, J. Chem. 
Educ. 64 (1987) 561-567. doi:10.1021/ed064p561.

[16] I. Langmuir, THE ADSORPTION OF GASES ON PLANE SURFACES OF GLASS, MICA AND PLATINUM., J. Am. Chem. Soc. 40 (1918) 1361-1403. doi:10.1021/ja02242a004.

[17] S. Azizian, S. Eris, L.D. Wilson, Re-evaluation of the century-old Langmuir isotherm for modeling adsorption phenomena in solution, Chem. Phys. 513 (2018) 99-104. doi:10.1016/j.chemphys.2018.06.022.

[18] J. chun Lee, Kurniawan, H.J. Hong, K.W. Chung, S. Kim, Separation of platinum, palladium and rhodium from aqueous solutions using ion exchange resin: A review, Sep. Purif. Technol. 246 (2020). doi:10.1016/j.seppur.2020.116896.

[19] M. Can, E. Bulut, M. Özacar, Synthesis and Characterization of Gallic Acid Resin and Its Interaction with Palladium(II), Rhodium(III) Chloro Complexes, Ind. Eng. Chem. Res. 51 (2012) 6052-6063. doi:10.1021/ie300437u.

[20] Ignasi Puigdomenech, Hydra and Medusa, R. Inst. Technol. Sweden. (2020) ver. 2020. https://www.kth.se/che/medusa/.

[21] M. Gregory, Measuring water solubility of platinum group metal containing substances, Johnson Matthey Technol. Rev. $58 \quad$ (2014) 212-216. doi:10.1595/205651314X684771.

[22] T.J.B. W. M. Haynes, David R. Lide, ed., CRC Handbook of Chemistry and Physics, 97th editi, CRC Press, 2016.

[23] H. Freundlich, Über die Adsorption in Lösungen, Zeitschrift Für Phys. Chemie. 57U (1907). doi:10.1515/zpch-1907-5723.

[24] V.P. M.I. Temkin, "Kinetics of ammonia synthesis on promoted iron catalyst," Acta USSR. 12 (1940) 327-356.

[25] M.M. Dubinin, The Potential Theory of Adsorption of Gases and Vapors for Adsorbents with Energetically Nonuniform Surfaces., Chem. Rev. 60 (1960) 235-241. 
doi:10.1021/cr60204a006.

[26] M.M. Dubinin, Fundamentals of the theory of adsorption in micropores of carbon adsorbents: Characteristics of their adsorption properties and microporous structures, Carbon N. Y. 27 (1989) 457-467. doi:10.1016/0008-6223(89)90078-X.

[27] O. Redlich, D.L. Peterson, A Useful Adsorption Isotherm, J. Phys. Chem. 63 (1959) 1024-1024. doi:10.1021/j150576a611.

[28] M. Can, Equilibrium, kinetics and process design of acid yellow 132 adsorption onto red pine sawdust, Water Sci. Technol. 71 (2015) 1901. doi:10.2166/wst.2015.164.

[29] K.Y. Foo, B.H. Hameed, Insights into the modeling of adsorption isotherm systems, Chem. Eng. J. 156 (2010) 2-10. doi:10.1016/j.cej.2009.09.013.

[30] N. Jasmeen, Synthesis of Titanium Oxide Nanotube via Hydrothermal Method and Recovery of Palladium by means of it, Open J. Nano. 2 (2013) 2-5.

[31] C. Shen, M. Min, L. Fang, J. Li, L. Yao, Y. Jiang, et al., Investigation of highly selective regenerative cellulose microcolumn for selenium detection and efficient recovery, Tetrahedron. 72 (2016) 8309-8318. doi:10.1016/j.tet.2016.11.003.

[32] Y.S. Ho, Selection of optimum sorption isotherm, Carbon N. Y. 42 (2004) 2115-2116. doi:10.1016/j.carbon.2004.03.019.

[33] E. Birinci, M. Gülfen, A.O. Aydin, Separation and recovery of palladium(II) from base metal ions by melamine-formaldehyde-thiourea (MFT) chelating resin, Hydrometallurgy. 95 (2009) 15-21. doi:10.1016/j.hydromet.2008.04.002.

[34] S. Sivrikaya, B. Karslı, M. Imamoglu, On-line Preconcentration of Pd(II) Using Polyamine Silica Gel Filled Mini Column for Flame Atomic Absorption Spectrometric Determination, Int. J. Environ. Res. 11 (2017) 579-590. doi:10.1007/s41742-0170051-1.

[35] K. Kaikake, M. Takada, D. Soma, R.H. Jin, Theophylline-bearing microspheres with dual 
features as a coordinative adsorbent and catalytic support for palladium ions, RSC Adv. 8 (2018) 34505-34513. doi:10.1039/C8RA06476H.

[36] V. VijayaKumar, C. Ramesh Kumar, A. Suresh, S. Jayalakshmi, U. Kamachi Mudali, N. Sivaraman, Evaluation of polybenzimidazole-based polymers for the removal of uranium, thorium and palladium from aqueous medium, R. Soc. Open Sci. 5 (2018). doi:10.1098/rsos.171701.

[37] M. Rovira, J.L. Cortina, J. Arnaldos, A.M. Sastre, Recovery and separation of platinum group metals using impregnated resins containing Alamine 336, Solvent Extr. Ion Exch. 16 (1998) 1279-1302. doi:10.1080/07360299808934580.

[38] J. Kramer, W.L. Driessen, K.R. Koch, J. Reedijk, Highly Selective and Efficient Recovery of Pd, Pt, and Rh from Precious Metal-Containing Industrial Effluents with Silica-Based (Poly)Amine Ion Exchangers, Sep. Sci. Technol. 39 (2004) 63-75. doi:10.1081/ss120027401.

[39] D. Jermakowicz-Bartkowiak, B.N. Kolarz, Poly(4-vinylpyridine) resins towards perrhenate sorption and desorption, React. Funct. Polym. 71 (2011) 95-103. doi:10.1016/j.reactfunctpolym.2010.11.023.

[40] M.H. Morcali, B. Zeytuncu, Investigation of adsorption parameters for platinum and palladium onto a modified polyacrylonitrile-based sorbent, Int. J. Miner. Process. 137 (2015) 52-58. doi:10.1016/j.minpro.2015.02.011.

[41] K. Fujiwara, A. Ramesh, T. Maki, H. Hasegawa, K. Ueda, Adsorption of platinum (IV), palladium (II) and gold (III) from aqueous solutions onto l-lysine modified crosslinked chitosan resin, J. Hazard. Mater. 146 (2007) 39-50. doi:10.1016/j.jhazmat.2006.11.049.

[42] A.B. Kanagare, K.K. Singh, K.K. Bairwa, R. Ruhela, V.S. Shinde, M. Kumar, et al., Dithiodiglycolamide impregnated XAD-16 beads for separation and recovery of 
palladium from acidic waste, J. Environ. Chem. Eng. 4 (2016) 3357-3363. doi:10.1016/j.jece.2016.06.031.

[43] A. Wołowicz, Z. Hubicki, Effect of matrix and structure types of ion exchangers on palladium(II) sorption from acidic medium, Chem. Eng. J. 160 (2010) 660-670. doi:10.1016/j.cej.2010.04.009.

[44] O.E. Fayemi, A.S. Ogunlaja, P.F.M. Kempgens, E. Antunes, N. Torto, T. Nyokong, et al., Adsorption and separation of platinum and palladium by polyamine functionalized polystyrene-based beads and nanofibers, Miner. Eng. 53 (2013) 256-265. doi:10.1016/j.mineng.2013.06.006.

[45] A.N. Turanov, V. Karandashev, O.I. Artyushin, E. V. Sharova, G.K. Genkina, Adsorption of palladium(II) from hydrochloric acid solutions using polymeric resins impregnated with novel N-substituted 2-(diphenylthiophosphoryl)acetamides, Sep. Purif. Technol. 187 (2017) 355-364. doi:10.1016/j.seppur.2017.06.068.

[46] O.A. Urucu, E.D. Aracier, E. Çakmakçi, Allylimidazole containing OSTE based photocured materials for selective and efficient removal of gold from aqueous media, Microchem. J. 146 (2019) 997-1003. doi:10.1016/j.microc.2019.02.041.

[47] F. Xie, Z. Fan, Q. Zhang, Z. Luo, Selective adsorption of Au3+ from aqueous solutions using persimmon powder-formaldehyde resin, J. Appl. Polym. Sci. 130 (2013) 39373946. doi:10.1002/app.39521.

[48] D. Jermakowicz-Bartkowiak, Polymer resins for recovery of valuable metals, Environ. Geochem. Health. 32 (2010) 317-320. doi:10.1007/s10653-010-9303-0.

[49] D. Jermakowicz-Bartkowiak, B.N. Kolarz, a. Serwin, Sorption of precious metals from acid solutions by functionalised vinylbenzyl chloride-acrylonitryle-divinylbenzene copolymers bearing amino and guanidine ligands, React. Funct. Polym. 65 (2005) 135-142. doi:10.1016/j.reactfunctpolym.2004.11.010. 
[50] a. M. Donia, a. a. Atia, K.Z. Elwakeel, Gold(III) recovery using synthetic chelating resins with amine, thio and amine/mercaptan functionalities, Sep. Purif. Technol. 42 (2005) 111-116. doi:10.1016/j.seppur.2004.06.009.

[51] H. Vojoudi, A. Badiei, A. Banaei, S. Bahar, S. Karimi, G. Mohammadi Ziarani, et al., Extraction of gold, palladium and silver ions using organically modified silica-coated magnetic nanoparticles and silica gel as a sorbent, Microchim. Acta. 184 (2017) 38593866. doi:10.1007/s00604-017-2414-X.

[52] Z. Dong, L. Zhao, Surface modification of cellulose microsphere with imidazoliumbased ionic liquid as adsorbent: effect of anion variation on adsorption ability towards Au(III), Cellulose. 25 (2018) 2205-2216. doi:10.1007/s10570-018-1735-1.

[53] Z. Dong, J. Liu, W. Yuan, Y. Yi, L. Zhao, Recovery of Au(III) by radiation synthesized aminomethyl pyridine functionalized adsorbents based on cellulose, Chem. Eng. J. 283 (2016) 504-513. doi:10.1016/j.cej.2015.07.011.

[54] H. Refiker, M. Merdivan, R.S. Aygun, Selective preconcentration of gold from ore samples, Int. J. Anal. Chem. 2018 (2018). doi:10.1155/2018/7503202.

[55] J. Zhao, C. Wang, S. Wang, L. Zhang, B. Zhang, Selective recovery of Au(III) from wastewater by a recyclable magnetic Ni0.6Fe2.404 nanoparticels with mercaptothiadiazole: Interaction models and adsorption mechanisms, J. Clean. Prod. 236 (2019). doi:10.1016/j.jclepro.2019.117605.

[56] J. Liu, C. Jin, C. Wang, Hyperbranched thiourea-grafted electrospun polyacrylonitrile fibers for efficient and selective gold recovery, J. Colloid Interface Sci. 561 (2020) 449458. doi:10.1016/j.jcis.2019.11.016.

[57] A. Dąbrowski, Adsorption - from theory to practice, Adv. Colloid Interface Sci. 93 (2001) 135-224. doi:10.1016/S0001-8686(00)00082-8.

[58] Y. Liu, Y.J. Liu, Biosorption isotherms, kinetics and thermodynamics, Sep. Purif. 
Technol. 61 (2008) 229-242. doi:10.1016/j.seppur.2007.10.002.

[59] S. Lagergren, About the theory of so-called adsorption of soluble substances (org.: Zur theorie der sogenannten adsorption gelöster stoffe), K. Sven. Vetenskapsakademiens Handl. 24 (1898) 1-39.

[60] Y.S. Ho, G. McKay, Pseudo-second order model for sorption processes, Process Biochem. (1999). doi:10.1016/S0032-9592(98)00112-5.

[61] M. Can, Investigation of the factors affecting acid blue 256 adsorption from aqueous solutions onto red pine sawdust: equilibrium, kinetics, process design, and spectroscopic analysis, Desalin. Water Treat. (2015) 1-18. doi:10.1080/19443994.2014.1003974.

[62] Ya. B. Zeldovich, Theoretical foundations of combustion processes, Acta Physicochim. U.R.S.S. 1 (1934) 449-469.

[63] S. Y. Elovich; G. M. Zhabrova, Mechanism of catalytic hydrogenation of ethylene on nickel. 1. Kinetics of the process, Zhur. Fiz. Khim. 13 (1939) 1761-1775.

[64] B.H. Stuart, Infrared Spectroscopy: Fundamentals and Applications, 2005. doi:10.1002/0470011149.

[65] M. Fathy, T. Abdel Moghny, A.E. Awad Allah, A.E. Alblehy, Cation exchange resin nanocomposites based on multi-walled carbon nanotubes, Appl. Nanosci. 4 (2014) 103-112. doi:10.1007/s13204-012-0178-5.

[66] L. Odeh, I. Odeh, M. Khamis, M. Khatib, M. Qurie, Z. Shakhsher, et al., Hexavalent Chromium Removal and Reduction to $\mathrm{Cr}$ (III) by Polystyrene Tris(2aminoethyl)amine, Am. J. Anal. Chem. $06 \quad$ (2015) 26-37. doi:10.4236/ajac.2015.61003.

[67] B. Gülbakan, C. Uzun, Ö. Çelikbiotaçak, O. Güven, B. Salih, Solid phase extraction of organochlorine pesticides with modified poly (styrene-divinylbenzene) microbeads 
using home-made solid phase extraction syringes, React. Funct. Polym. 68 (2008) 580-593. doi:10.1016/j.reactfunctpolym.2007.10.014.

[68] Y. Peng, P. Wu, A two dimensional infrared correlation spectroscopic study on the structure changes of PVDF during the melting process, Polymer (Guildf). 45 (2004) 5295-5299. doi:10.1016/j.polymer.2004.05.034. 
